FOLIA POMERANAE UNIVERSITATIS TECHNOLOGIAE STETINENSIS

Folia Pomer. Univ. Technol. Stetin., Oeconomica 2017, 335(87)2, 167-180

Iwona MAJCHRZAK, Anna ZBARASZEWSKA*

\title{
AUTORYTET NAUCZYCIELI AKADEMICKICH WEDŁUG OPINII STUDENTÓW
}

\section{AUTHORITY OF LECTURER IN THE OPINION OF STUDENT}

Zakład Ekonomii i Rachunkowości, Zachodniopomorski Uniwersytet Technologiczny w Szczecinie ul. Żołnierska 47, 71-210 Szczecin, e-mail: imajchrzak@zut.edu.pl

*Instytut Rachunkowości, Uniwersytet Szczeciński

ul. Adama Mickiewicza 64, 71-101 Szczecin, e-mail:aniazba@wp.pl

\begin{abstract}
Summary. The aim of this article is to identify the characteristics which should be characterized by a university teacher who is an authority on student opinion. Development of the article preceded by literature studies and surveys conducted among university students. The main method used in the article is the analysis of the sources and the method of deduction and induction. The study allowed us to develop a set of characteristics of an academic teacher's authority. The content in this article are the description of the silhouette of an academic teacher in the literature, and on the basis of the conducted survey.
\end{abstract}

Słowa kluczowe: autorytet, nauczyciel akademicki, cechy nauczyciela akademickiego.

Key words: authority, tutor, university teacher's characteristics.

\section{WSTĘP}

Sprawne funkcjonowanie jednostki w społeczeństwie wymaga budowania właściwych relacji międzyludzkich opartych na działaniu i interakcji uczuć oraz postaw. W związku z tym istotny staje się autorytet, rozumiany jako działanie innych osób, bez względu na ich osobisty stosunek do tego (Parsons 1971). Tak rozumiane działanie może wywierać osoba sprawująca urząd lub o innym społecznie określonym statusie, czyli np. nauczyciel akademicki.

W literaturze przedmiotu jednak coraz częściej można odnaleźć badania wskazujące na zanik lub upadek tradycyjnych autorytetów, w tym autorytetu nauczyciela akademickiego wśród studentów (Polok 2010; Śnieżyński 2000). Również badania przeprowadzone przez Centrum Badania Opinii Społecznej ${ }^{1}$, dotyczące społecznej hierarchii prestiżu zawodów, wskazują, iż mimo że w dalszym ciągu zawód profesora uniwersytetu zajmuje wysoką pozycję, na przestrzeni lat obserwuje się jego spadek.

W celu określenia przyczyn takiego stanu podejmowane są wielokierunkowe badania oraz próby wskazania sposobów odbudowy nadwątlonego autorytetu zawodu nauczyciela.

Również autorki niniejszego artykułu podjęły trud zebrania opinii studentów dwóch szczecińskich uczelni kształcących przyszłych ekonomistów na temat autorytetu nauczycieli

\footnotetext{
${ }^{1}$ Badanie „Aktualne problemy i wydarzenia” przeprowadzono metodą wywiadów bezpośrednich (face-to-face) wspomaganych komputerowo (CAPI), w dniach 1-12 sierpnia 2013 roku, na liczącej 904 osoby reprezentatywnej próbie losowej dorosłych mieszkańców Polski - zob. www.cbos.pl.
} 
akademickich. Tym samym celem artykułu jest przedstawienie ich opinii na ten temat oraz wskazanie cech charakteryzujących nauczyciela akademickiego z autorytetem.

\section{MATERIAŁ I METODY}

Opracowanie artykułu poprzedziły studia literaturowe dotyczące znaczenia pojęcia „autorytet” i czynników składających się na cechy, którymi powinna charakteryzować się osoba z autorytetem. Rozważania w tym zakresie zostały bezpośrednio odniesione do zawodu nauczyciela akademickiego jako podmiotu badań. Przeprowadzone badania literaturowe stanowiły również podstawę wyboru metody i narzędzia badawczego oraz sformułowania pytań badawczych.

Na podstawie opracowanego kwestionariusza ankiety w listopadzie 2016 roku na wydziałach ekonomicznych dwóch szczecińskich uczelni - Uniwersytetu Szczecińskiego i Zachodniopomorskiego Uniwersytetu Technologicznego w Szczecinie zostały przeprowadzone badania ankietowe.

Wykorzystany do badań kwestionariusz ankiety zawierał 7 pytań, z których 2 pytania miały charakter pytań umożliwiających wskazanie więcej niż jednej odpowiedzi, 2 pytania umożliwiały udzielenie jednej z dwóch odpowiedzi, natomiast 3 pytania zawierały listę cech, którym respondenci przypisywali oceny w skali punktowej od 1 do 5; przy czym ocena 1 oznaczała cechę najmniej pożądaną według opinii respondentów, natomiast ocena 5 - najbardziej pożądaną.

W badaniu łącznie uczestniczyło 176 studentów, w tym 102 studentów z Wydziału Nauk Ekonomicznych i Zarządzania Uniwersytetu Szczecińskiego, a 74 z Wydziału Ekonomicznego Zachodniopomorskiego Uniwersytetu Technologicznego w Szczecinie. Respondenci, biorący udział w badaniu, są studentami różnych roczników, kierunków studiów i form kształcenia na badanych uczelniach. Liczebność respondentów przedstawiono na ryc. 1.
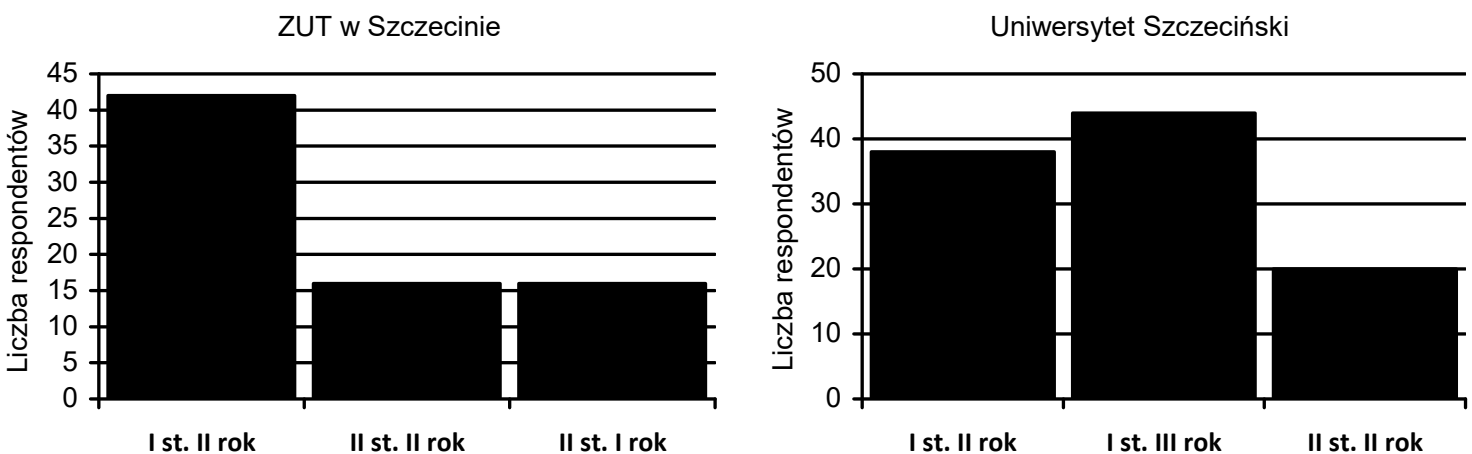

Ryc. 1. Liczebność respondentów z poszczególnych uczelni Źródło: wyniki badań ankietowych.

Z uwagi na znaczne zróżnicowanie próby badawczej na potrzeby analizy i interpretacji uzyskanych wyników przeprowadzonego badania przyjęto, iż jedynym kryterium różnicowania będzie miejsce studiowania respondenta. Stwierdzono, iż takie uproszczenie nie będzie 
zniekształcało uzyskanych wyników, a jedynie przyczyni się do przejrzystości formułowanych wniosków badawczych. Wnioski przedstawione w niniejszym artykule wynikają również z własnych obserwacji i doświadczeń autorek.

\section{AUTORYTET I JEGO ZNACZENIE W LITERATURZE PRZEDMIOTU}

W literaturze przedmiotu pojęcie „autorytet” nie jest jednoznaczne. Można go rozpatrywać w różnych ujęciach. Pojęcie „autorytet” pochodzi od łacińskiego słowa auctoritas, co pierwotnie oznaczało wpływ osobisty, znaczenie, przywództwo, odpowiedzialność, a także było określeniem grupy mężczyzn stanowiących wzmocnienie władzy rzymskiej (Błędowska 1996).

Obecnie potocznie autorytet oznacza posiadanie uznania, szacunku i władzy. Słowniki definiują to pojęcie jako społeczne uznanie, prestiż osób, grup i instytucji społecznych oparte na cenionych w danym społeczeństwie wartościach, a także osoby, instytucje cieszące się uznaniem (Nowy leksykon PNW 1998). Tym samym autorytet może być rozpatrywany jako przymiot, cecha, właściwość osoby, która go posiada, a przy tym może być także podmiotem właściwości, gdy ktoś jest autorytetem (Polok 2010).

W rozumieniu naukowym autorytet to relacja przestrzenna istniejąca między co najmniej dwiema osobami, w której jedna strona występuje w roli instancji wskazującej drugiej stronie określony kierunek postępowania (Polok 2010). Najczęściej autorytetami stają się osoby, które incydentalnie myślą o tym, by autorytetem zostać, a zasadniczo nie mają takiego pragnienia (Łobocki 2007).

W literaturze przedmiotu wyróżnia się różne rodzaje autorytetu, których charakterystykę zaprezentowano w tab. 1.

Tabela 1. Rodzaje autorytetu i ich charakterystyka

\begin{tabular}{|c|c|}
\hline Rodzaj autorytetu & Charakterystyka \\
\hline Autorytet wewnętrzny & $\begin{array}{l}\text { charakteryzuje się dobrowolną uległością innych osób i ich gotowością do } \\
\text { podporządkowania się ze względu na odczuwany podziw i uznanie, } \\
\text { przypisywany jest danej osobie ze względu na jej cechy charakteru i wartości, } \\
\text { które uznaje i realizuje w swoim życiu }\end{array}$ \\
\hline Autorytet zewnętrzny & $\begin{array}{l}\text { w odróżnieniu od autorytetu wewnętrznego występuje w sytuacji, gdy } \\
\text { podporządkowanie nie jest dobrowolne; jest on przypisywany ze względu na } \\
\text { stanowisko podmiotu autorytetu w hierarchii władzy lub pełnienie odpowiedniej } \\
\text { funkcji }\end{array}$ \\
\hline Autorytet wyzwalający & $\begin{array}{l}\text { charakteryzuje się inspirującym i konstruktywnym wpływem na postępowanie } \\
\text { osób, których uznaniem się cieszy; ma szczególne znaczenie w pracy z dziećmi } \\
\text { i młodzieżą }\end{array}$ \\
\hline Autorytet ujarz & $\begin{array}{l}\text { wypływa nie z osobistych zalet czy zasług osoby, lecz z jej wygórowanej ambicji } \\
\text { i żądzy władzy }\end{array}$ \\
\hline $\begin{array}{l}\text { Autorytet znawcy } \\
\text { (intelektualny, } \\
\text { epistemologiczny) }\end{array}$ & $\begin{array}{l}\text { przysługuje osobie ze względu na jej rozległą wiedzą i kompetencje; osoba } \\
\text { będąca autorytetem intelektualnym posiada indywidualny warsztat badawczy } \\
\text { oraz jest twórcą i autorem dzieł wzorcowych }\end{array}$ \\
\hline $\begin{array}{l}\text { Autorytet moralny } \\
\text { (osobisty, wychowawczy) }\end{array}$ & $\begin{array}{l}\text { osoba o takim autorytecie staje się dla innych wzorem postępowania moralnego } \\
\text { ze względu na cechy swojego charakteru oraz wrażliwość na innych ludzi, } \\
\text { zwłaszcza pokrzywdzonych przez los i potrzebujących. Ten rodzaj autorytetu } \\
\text { jest cennym źródłem inspiracji i motywacji do zachowań moralnie war- } \\
\text { tościowych; połączony jest z cechami osobowości jego podmiotu, a uznanie } \\
\text { osoby następuje dzięki realizacji przez nią w codziennym życiu określonych } \\
\text { norm i wartości moralnych }\end{array}$ \\
\hline
\end{tabular}

Źródło: opracowano na podstawie: Polok (2010); Błędowska (1996). 
Z pedagogicznego punktu widzenia istotne jest wyodrębnienie autorytetu wewnętrznego i wyzwalającego oraz autorytetu znawstwa i autorytetu moralnego. Te rodzaje autorytetów są bowiem nazywane autorytetami prawdziwymi. Tym samym powinny być najbardziej pożądane przez nauczycieli, w tym nauczycieli akademickich.

Rozpatrując zagadnienie autorytetu nauczycieli akademickich, nie można pominąć ich roli zawodowej.

W literaturze przedmiotu (Jaskot i Jazukiewicz 2006) wyróżnia się 4 podstawowe role zawodowe nauczycieli akademickich, tj. pracownika naukowego, dydaktyka, wychowawcy oraz organizatora.

Zgodnie z Ustawą z dnia 27 lipca 2005 r. Prawo o szkolnictwie wyższym do zadań pracownika naukowego należy:

- prowadzenie badań naukowych i prac rozwojowych,

- rozwijanie twórczości naukowej lub artystycznej,

- uczestniczenie w pracach organizacyjnych uczelni.

Rola dydaktyka w przypadku nauczyciela akademickiego jest ściśle związana z zadaniami wykonywanymi w ramach powierzonych mu obowiązków. Jako dydaktyk nauczyciel akademicki powinien bowiem przekazywać słuchaczom wiedzę, którą sam stworzył w ramach prowadzonych badań naukowych i prac rozwojowych.

Rola wychowawcza nauczyciela akademickiego powinna być realizowana na płaszczyźnie indywidualnej oraz społecznej. Wymiar indywidualny jest związany z rozwojem i kształtowaniem osobowości studenta, natomiast wymiar społeczny $-z$ przystosowaniem absolwenta do funkcjonowania w społeczeństwie.

Nauczyciel akademicki jako organizator podejmuje działania wobec samego siebie, organizując swój warsztat pracy. Organizuje ponadto pracę studentów oraz młodszych pracowników nauki wskazując im kierunki rozwoju i możliwości podejmowania różnego rodzaju aktywności w zakresie prac naukowych. Ponadto przyczynia się do reformowania szkolnictwa wyższego i kreowania uczelni na miarę potrzeb XXI wieku (Wiśniewska 2011).

Według opinii pracowników nauki oraz studentów wyznacznikami autorytetu nauczyciela akademickiego są (Śnieżyński 2000):

a) rozległa i gruntowna wiedza teoretyczna oraz praktyczna, a także szerokie horyzonty myślowe,

b) doskonała znajomość warsztatu naukowego,

c) zdolności i umiejętności metodyczne,

d) umiejętność wytyczania nowych dróg w myśleniu i działaniu,

e) osiągnięcia w tworzeniu wiedzy naukowej poparte dorobkiem naukowym,

f) umiejętność organizowania działalności naukowej i inspirowania innych do podejmowania badań,

g) uczciwość i rzetelność naukowa oraz szeroko rozumiana etyka.

Role zawodowe nauczycieli akademickich i wynikające z nich cechy automatycznie wskazują, iż ta grupa zawodowa powinna cieszyć się w środowisku, w którym funkcjonuje, autorytetem. Wynika to również z faktu, iż właściwe wykonywanie powierzonych nauczycielom akademickich zadań wymaga teoretycznego opanowania wiedzy naukowej na wysokim poziomie oraz zdobycia umiejętności praktycznych, przy jednoczesnym przestrzeganiu zasad etyki, wolności i autonomii, co w konsekwencji ma duże znaczenie społeczne i generuje autorytet (Hörner 2000). 


\section{WYNIKI I DYSKUSJA}

Punktem wyjścia przeprowadzonych badań ankietowych było poznanie opinii respondentów na temat rozumienia przez nich pojęcia „autorytet”. Dla badanych studentów autorytet dotyczył osoby będącej wzorem do naśladowania (100\% wskazań respondentów z Zachodniopomorskiego Uniwersytetu Technologicznego i 90\% wskazań studentów Uniwersytetu Szczecińskiego), wzbudzającej szacunek i podziw (odpowiednio 94\% i 75\% wskazań). W dalszej kolejności wskazali na to, że osoba ta powinna kierować się w życiu określonymi zasadami i wartościami, posiadać powinna tzw. kręgosłup moralny (56\% i 40\% wskazań). Według opinii respondentów autorytetem cieszy się osoba, która wzbudza zaufanie, daje poczucie bezpieczeństwa (38\% wskazań studentów Zachodniopomorskiego Uniwersytetu Technologicznego i 15\% wskazań studentów Uniwersytetu Szczecińskiego). Sporą rozbieżność w rozumieniu pojęcia „autorytet” można zauważyć przy odpowiedziach opisujących autorytet dotyczący osoby potrafiącej pomagać i wspierać (44\% grupy respondentów Zachodniopomorskiego Uniwersytetu Technologicznego i $20 \%$ wskazań grupy Uniwersytetu Szczecińskiego). Dla połowy respondentów z Zachodniopomorskiego Uniwersytetu Technologicznego osoba będąca dla nich autorytetem cechuje się silną charyzmą, natomiast dla studentów Uniwersytetu Szczecińskiego ta cecha nie była w ogóle istotna, gdyż wskazało na nią jedynie $10 \%$ respondentów.

Respondenci niechętnie podawali własne cechy autorytetu, jedynie respondenci z Zachodniopomorskiego Uniwersytetu Technologicznego wskazali, że osoba z autorytetem to osoba intrygująca, wzbudzająca powszechne uznanie.

Autorytet nauczyciela akademickiego, wynikający z posiadanej wiedzy oraz umiejętności przekazywania jej studentom, wywiera znaczny wpływ na efektywność procesu kształcenia. Przeprowadzone wśród studentów wyższych uczelni w latach 90. ubiegłego wieku badania pozwoliły na wyodrębnienie cech pozytywnych i negatywnych kształtujących wizerunek nauczyciela akademickiego (Zbaraszewska i Majchrzak 2016). Cechy te są zaprezentowane w tab. 2.

Tabela 2. Pozytywne i negatywne cechy nauczyciela akademickiego

\begin{tabular}{|c|c|c|}
\hline Autor badania & Cechy pozytywne & Cechy negatywne \\
\hline Bogusz (1996) & $\begin{array}{l}\text { sprawiedliwość } \\
\text { inteligencja } \\
\text { cierpliwość } \\
\text { wyrozumiałość } \\
\text { wymagalność } \\
\text { stanowczość } \\
\text { precyzyjność w wyrażaniu myśli } \\
\text { estetyczny wygląd } \\
\text { poczucie humoru }\end{array}$ & $\begin{array}{l}\text { niesprawiedliwość } \\
\text { ordynarność } \\
\text { nerwowość } \\
\text { luki w wiedzy } \\
\text { brak zdolności w przekazywaniu wiedzy } \\
\text { dwulicowość } \\
\text { zarozumialstwo }\end{array}$ \\
\hline Haber (1996) & $\begin{array}{l}\text { profesjonalizm } \\
\text { komunikatywność } \\
\text { współpraca } \\
\text { obiektywizm } \\
\text { wyrozumiałość } \\
\text { zdyscyplinowanie }\end{array}$ & $\begin{array}{l}\text { zarozumiałość } \\
\text { niekompetentność } \\
\text { niekomunikatywność } \\
\text { subiektywizm } \\
\text { rutyna w działaniu } \\
\text { niezdyscyplinowanie }\end{array}$ \\
\hline
\end{tabular}

Źródło: opracowano na podstawie: Bogusz (1996); Haber (1996). 
Bycie autorytetem dla drugiego człowieka oznacza reprezentowanie określonych wartości i postaw moralnych, co - w obliczu znamiennego dla współczesnych czasów przewartościowywania norm etycznych, zestawu życiowych priorytetów, uznawanych dotychczas za niepodważalne - wydaje się kwestią szczególnie istotną w rozważaniach nad wizerunkiem obecnej kadry naukowej. Normatywne modele osobowości pracowników naukowo-dydaktycznych, pojawiające się w wielu wcześniejszych opracowaniach, nie muszą być aktualne dla studiujących. Można spróbować odpowiedzieć na pytanie, jakie cechy powinien mieć nauczyciel akademicki XXI w. cieszący się autorytetem.

Przeprowadzone badanie w dalszej części dotyczyło wskazania hierarchii cech osobowości, dydaktycznych i zewnętrznych kształtujących autorytet nauczyciela akademickiego.

Odpowiadając na zadane pytanie, respondenci mieli możliwość oceny cech osobowości nauczyciela z autorytetem w skali od 1 (bardzo niepożądana cecha) do 5 (bardzo pożądana cecha). Zestawienie cech osobowościowych, jakimi powinien odznaczać się nauczyciel z autorytetem według opinii respondentów z poszczególnych uczelni, przedstawiono odpowiednio $w$ tab. 3 i tab. 4.

Tabela 3. Cechy osobowości nauczyciela cieszącego się autorytetem według opinii studentów Uniwersytetu Szczecińskiego

\begin{tabular}{|l|c|}
\hline \multicolumn{1}{|c|}{ Cecha osobowości wykładowcy } & Średnia ocena cechy \\
\hline Uczciwość & 4,90 \\
\hline Sprawiedliwość & 4,65 \\
\hline Odpowiedzialność & 4,40 \\
\hline Obiektywizm & 4,35 \\
\hline Szanowanie poglądów innych osób & 4,30 \\
\hline Umiejętność przyznawania się do własnych błędów & 4,30 \\
\hline Otwartość & 4,20 \\
\hline Tolerancyjność & 3,95 \\
\hline Wyrozumiałość & 3,90 \\
\hline Uprzejmość & 3,90 \\
\hline Empatia & 3,85 \\
\hline Życzliwość & 3,75 \\
\hline Bezpośredniość w kontaktach interpersonalnych & 3,60 \\
\hline Opiekuńczość & 3,35 \\
\hline Skromność & 2,80 \\
\hline
\end{tabular}

Źródło: opracowano na podstawie wyników przeprowadzonych badań ankietowych.

Tabela 4. Cechy osobowości nauczyciela cieszącego się autorytetem według opinii studentów Zachodniopomorskiego Uniwersytetu Technologicznego w Szczecinie

\begin{tabular}{|l|c|}
\hline \multicolumn{1}{|c|}{ Cecha osobowości wykładowcy } & Średnia ocena cechy \\
\hline Uczciwość & 4,60 \\
\hline Umiejętność przyznawania się do własnych błędów & 4,60 \\
\hline Obiektywizm & 4,60 \\
\hline Życzliwość & 4,60 \\
\hline Sprawiedliwość & 4,50 \\
\hline Uprzejmość & 4,40 \\
\hline Otwartość & 4,40 \\
\hline Szanowanie poglądów innych osób & 4,40 \\
\hline Wyrozumiałość & 4,30 \\
\hline Odpowiedzialność & 4,10 \\
\hline Empatia & 4,10 \\
\hline Bezpośredniość w kontaktach interpersonalnych & 3,70 \\
\hline Tolerancyjność & 3,40 \\
\hline Opiekuńczość & 3,30 \\
\hline Skromność & 3,10 \\
\hline
\end{tabular}

Źródło: opracowano na podstawie wyników przeprowadzonych badań ankietowych. 
Przeprowadzone badania empiryczne wśród studentów wydziałów ekonomicznych dwóch szczecińskich uczelni wyższych wykazały zbliżone wyniki w zakresie oceny cech wykładowcy cieszącego się autorytetem, przy czym otrzymały one nieco inną średnią ocenę punktową.

Wszyscy respondenci ocenili wskazane cechy powyżej 2, jednak żadna spośród 15 cech nie otrzymała najwyższej noty. Najwyżej oceniona cecha według opinii studentów obu szczecińskich uczelni uzyskała średnią ocenę 4,90 (studenci Uniwersytetu Szczecińskiego) i 4,60 (respondenci z Zachodniopomorskiego Uniwersytetu Technologicznego w Szczecinie). Najwyższe noty otrzymała ta sama cecha - uczciwość, co wskazuje na to, że respondenci uważają, że nauczyciel akademicki cieszący się autorytetem to nie tylko reprezentant wiedzy, ale przede wszystkim wzorzec osobowy.

Ocena kolejnych cech osobowościowych w przypadku obu grup respondentów znacznie się różni, aczkolwiek można stwierdzić, że podobne cechy są wskazywane jako najważniejsze dla tworzenia autorytetu.

Dla studentów Uniwersytetu Szczecińskiego istotną cechą jest sprawiedliwość (ocena $4,65)$, która według opinii studentów drugiej uczelni została oceniona zdecydowanie niżej (ocena 4,50) i uplasowała się nieco niżej w rankingu cech.

Kolejna cecha, wskazana przez uczestników badania z Uniwersytetu Szczecińskiego, to odpowiedzialność (ocena 4,40), która dla drugiej grupy okazała się mniej istotna (ocena 4,10 ) i znalazła się w grupie cech mniej pożądanych w budowaniu autorytetu.

Dla obu grup respondentów bardzo istotny jest obiektywizm (odpowiednio 4,35 i 4,60).

Osoba posiadająca autorytet dla obu grup to osoba, która szanuje poglądy innych osób (ocena na poziomie 4,30 i 4,40) i potrafi przyznać się do własnych błędów (odpowiednio oceny 4,30 i 4,60$)$.

Pozostałe cechy wymienione $\mathrm{w}$ ankiecie były dla obu grup respondentów jednakowo ważne, co spowodowało, że pomimo rozbieżności w ocenie punktowej ich kolejność w rankingu cech jest niemal identyczna.

Osoba ciesząca się autorytetem według obu grup powinna charakteryzować się otwartością (odpowiednio 4,20 i 4,40), wyrozumiałością (3,90 i 4,30), empatią (3,85 i 4,10) oraz bezpośredniością w kontaktach interpersonalnych (3,60 i 3,70), a także opiekuńczością (3,35 i 3,30).

Nieco odmienne oceny dotyczyły takich cech, jak: tolerancyjność (ocena 3,95 i 3,30) i życzliwość (ocena 3,75 i 4,60).

Wskazać należy również na to, że respondenci z Uniwersytetu Szczecińskiego, oprócz dwóch cech - uczciwości i sprawiedliwości, pozostałe cechy ocenili zdecydowanie niżej niż respondenci z Zachodniopomorskiego Uniwersytetu Technologicznego.

Najmniej pożądaną cechą idealnego nauczyciela akademickiego według opinii studentów obu szczecińskich uczelni okazała się skromność. Respondenci cechę tę ocenili średnio odpowiednio na 2,80 i 3,10 punkta. Na podstawie uzyskanego wyniku można wnioskować, że ta cecha nie jest obecnie w „modzie” i że nie wpływa w istotny sposób na autorytet wykładowcy.

Przeprowadzone badania wykazały, iż nie ma znacznych różnic w opiniach studentów szczecińskich uczelni na temat cech osobowościowych nauczyciela akademickiego postrzeganego jako autorytet.

Przedstawione w tab. 5 zestawienie cech osobowościowych wykładowcy jednoznacznie potwierdziło przeprowadzoną analizę wyników na podstawie średniej oceny punktowej przyznawanej przez studentów Uniwersytetu Szczecińskiego i Zachodniopomorskiego 
Uniwersytetu Technologicznego w Szczecinie. Mimo iż uzyskane wyniki średnie są nieco odmienne (co oznacza, że respondenci poszczególnym cechom nadali różną liczbę punktów), kolejność cech uszeregowana od najwyższej punktacji według opinii studentów tych uczelni jest niemal identyczna. Dla tych respondentów najważniejszą cechą nauczyciela akademickiego, który jest dla nich autorytetem, jest uczciwość, a najmniej istotną - skromność.

Tabela 5. Porównanie cech osobowościowych nauczyciela cieszącego się autorytetem, wskazanych przez respondentów

\begin{tabular}{|l|l|}
\multicolumn{1}{|c|}{ Uniwersytet Szczeciński } & \multicolumn{1}{|c|}{$\begin{array}{c}\text { Zachodniopomorski Uniwersytet Technologiczny } \\
\text { w Szczecinie }\end{array}$} \\
\hline uczciwość & uczciwość \\
\hline sprawiedliwość & umiejętność przyznawania się do własnych błędów \\
\hline odpowiedzialność & obiektywizm \\
\hline obiektywizm & życzliwość \\
\hline szanowanie poglądów innych osób & sprawiedliwość \\
\hline umiejętność przyznawania się do własnych błędów & uprzejmość \\
\hline otwartość & otwartość \\
\hline tolerancyjność & szanowanie poglądów innych osób \\
\hline wyrozumiałość & wyrozumiałość \\
\hline uprzejmość & odpowiedzialność \\
\hline empatia & empatia \\
\hline życzliwość & bezpośredniość w kontaktach interpersonalnych \\
\hline bezpośredniość w kontaktach interpersonalnych & tolerancyjność \\
\hline opiekuńczość & opiekuńczość \\
\hline skromność & skromność \\
\hline
\end{tabular}

Źródło: opracowano na podstawie wyników przeprowadzonych badań własnych.

Zestawienie cech dydaktycznych nauczyciela akademickiego cieszącego się autorytetem, uszeregowanych od najwyższej punktacji, według opinii respondentów z poszczególnych uczelni, przedstawiono odpowiednio w tab. 6 i tab. 7.

Przeprowadzone badania ponownie wykazały zbliżone wyniki dotyczące oceny cech dydaktycznych wykładowcy, przy czym cechy te otrzymały nieco inną średnią ocenę punktową. Grupa respondentów Uniwersytetu Szczecińskiego oceniła zdecydowanie "ostrożniej” wymienione w badaniu cechy niż grupa studentów z Zachodniopomorskiego Uniwersytetu Technologicznego.

Tabela 6. Cechy dydaktyczne nauczyciela cieszącego się autorytetem według opinii studentów Uniwersytetu Szczecińskiego

\begin{tabular}{|l|c|}
\hline \multicolumn{1}{|c|}{ Cecha dydaktyczna wykładowcy } & Średnia ocena cechy \\
\hline Posiadanie wiedzy praktycznej & 4,85 \\
\hline Kompetencje merytoryczne i metodyczne & 4,60 \\
\hline Posiadanie wiedzy teoretycznej & 4,55 \\
\hline Przygotowanie do zajęć & 4,35 \\
\hline Pasja & 4,25 \\
\hline Komunikatywność & 4,20 \\
\hline Obiektywność & 4,10 \\
\hline Uwzględnianie potrzeb uczących się osób & 4,05 \\
\hline Kreatywność & 3,90 \\
\hline Sumienność & 3,85 \\
\hline Otwartość na nowości & 3,75 \\
\hline Indywidualizacja nauczania & 3,40 \\
\hline Punktualność & 3,40 \\
\hline
\end{tabular}

Źródło: opracowano na podstawie wyników przeprowadzonych badań ankietowych. 
Tabela 7. Cechy dydaktyczne nauczyciela cieszącego się autorytetem według opinii studentów Zachodniopomorskiego Uniwersytetu Technologicznego

\begin{tabular}{|l|c|}
\hline \multicolumn{1}{|c|}{ Cecha dydaktyczna wykładowcy } & Średnia ocena cechy \\
\hline Kompetencje merytoryczne i metodyczne & 4,90 \\
\hline Posiadanie wiedzy praktycznej & 4,80 \\
\hline Komunikatywność & 4,80 \\
\hline Posiadanie wiedzy teoretycznej & 4,50 \\
\hline Obiektywność & 4,40 \\
\hline Otwartość na nowości & 4,30 \\
\hline Uwzględnianie potrzeb uczących się osób & 4,30 \\
\hline Sumienność & 4,30 \\
\hline Przygotowanie do zajęć & 4,25 \\
\hline Kreatywność & 4,25 \\
\hline Pasja & 4,20 \\
\hline Punktualność & 3,90 \\
\hline Indywidualizacja nauczania & 3,70 \\
\hline
\end{tabular}

Źródło: opracowano na podstawie wyników przeprowadzonych badań ankietowych.

Wszyscy respondenci ocenili wskazane cechy na powyżej 3 pkt, jednak żadna spośród 13 cech nie otrzymała maksymalnej oceny. Najwyżej oceniona cecha przez studentów obu szczecińskich uczelni uzyskała średnią ocenę 4,60 (studenci Uniwersytetu Szczecińskiego) i 4,90 (respondenci z Zachodniopomorskiego Uniwersytetu Technologicznego w Szczecinie). Oceny te dotyczą kompetencji merytorycznych i metodycznych, jakie powinien posiadać wykładowca wyższej uczelni. Dla studentów Uniwersytetu Szczecińskiego najważniejszą cechą okazało się posiadanie wiedzy praktycznej, które zostało przez nich najwyżej ocenione (ocena 4,85), co z kolei według oceny studentów Zachodniopomorskiego Uniwersytetu Technologicznego było nieco mniej istotne (ocena 4,80) niż posiadane kompetencje.

Bardzo istotną cechą dla obu grup jest też posiadanie wiedzy teoretycznej (oceny odpowiednio na poziomie 4,55 i 4,50).

Zdecydowane różnice w ocenie widać na przykładzie dwóch cech - przygotowania się do zajęć, które dla studentów Uniwersytetu Szczecińskiego okazało się bardzo istotną cechą (ocenioną na 4,35) i uplasowało się wysoko w rankingu cech, natomiast dla drugiej grupy respondentów cecha ta była mniej istotna, co spowodowało uplasowanie się tej cechy pod koniec rankingu cech sporządzonych na podstawie opinii studentów Zachodniopomorskiego Uniwersytetu Technologicznego.

Podobnie oceniona została pasja, która dla studentów Uniwersytetu Szczecińskiego jest bardzo ważną cechą, natomiast dla studentów Zachodniopomorskiego Uniwersytetu Technologicznego cecha ta jest zdecydowanie mniej pożądana.

Studenci Zachodniopomorskiego Uniwersytetu Technologicznego wskazali natomiast, że ważną cechą budującą autorytet dydaktyczny jest komunikatywność (ocena 4,80), co nie znalazło potwierdzenia w ocenie studentów Uniwersytetu Szczecińskiego, którzy cechę tę ocenili na 4,20 pkt.

Podobnie oceniona została otwartość na nowości, która dla respondentów z Zachodniopomorskiego Uniwersytetu Technologicznego była bardzo istotna (ocena 4,30), natomiast dla studentów drugiej uczelni - mało istotna (ocena 3,75 ). 
W podobnej kolejności uplasowały się w rankingach obu grup respondentów takie cechy, jak: obiektywność, uwzględnianie potrzeb uczących się osób, sumienność i kreatywność.

Najniżej ocenione zostały dwie cechy - punktualność $(3,40$ i 3,90) oraz indywidualizacja w nauczaniu $(3,40$ i 3,70).

Zestawienie cech dydaktycznych respondentów obu uczelni, sporządzone na podstawie oceny punktowej, w porządku malejącym przedstawiono w tab. 8.

Tabela 8. Porównanie cech dydaktycznych nauczyciela cieszącego się autorytetem, wskazanych przez respondentów

\begin{tabular}{|l|l|}
\multicolumn{1}{|c|}{ Uniwersytet Szczeciński } & \multicolumn{1}{c|}{$\begin{array}{c}\text { Zachodniopomorski Uniwersytet Technologiczny } \\
\text { w Szczecinie }\end{array}$} \\
\hline posiadanie wiedzy praktycznej & kompetencje merytoryczne i metodyczne \\
\hline kompetencje merytoryczne i metodyczne & posiadanie wiedzy praktycznej \\
\hline posiadanie wiedzy teoretycznej & komunikatywność \\
\hline przygotowanie do zajęć & posiadanie wiedzy teoretycznej \\
\hline pasja & obiektywność \\
\hline komunikatywność & otwartość na nowości \\
\hline obiektywność & uwzględnianie potrzeb uczących się osób \\
\hline uwzględnianie potrzeb uczących się osób & sumienność \\
\hline kreatywność & przygotowanie się do zajęć \\
\hline sumienność & kreatywność \\
\hline otwartość na nowości & pasja \\
\hline indywidualizacja nauczania & punktualność \\
\hline punktualność & indywidualizacja nauczania \\
\hline
\end{tabular}

Źródło: opracowano na podstawie wyników przeprowadzonych badań własnych.

W badaniu ankietowym zostały poddane ocenie przez respondentów także cechy zewnętrzne, które wpływają na wizerunek nauczyciela akademickiego, który posiada autorytet.

Przeprowadzone badania tak jak w poprzednich przypadkach wykazały zbliżone wyniki dotyczące oceny cech zewnętrznych wykładowcy. W tym przypadku respondenci z obu uczelni byli zgodni w tym, że osoba będąca dla nich autorytetem powinna odznaczać się kulturą osobistą i taktem. Powinna to być osoba z poczuciem humoru, pewna siebie w pozytywnym tego słowa znaczeniu, o schludnym i zadbanym wyglądzie. Najmniej istotne dla respondentów było to, czy osoba ta posiada własny styl bycia i stosowny elegancki ubiór. Wyniki z podanymi ocenami respondentów z Uniwersytetu Szczecińskiego i Zachodniopomorskiego Uniwersytetu Technologicznego zaprezentowane są w tab. 9 i tab. 10.

Tabela 9. Cechy zewnętrzne - wizerunek nauczyciela z autorytetem według opinii studentów Uniwersytetu Szczecińskiego

\begin{tabular}{|l|c|}
\hline \multicolumn{1}{|c|}{ Cecha wykładowcy } & Średnia ocena cechy \\
\hline Kultura osobista & 4,70 \\
\hline Taktowność & 4,15 \\
\hline Schludny zadbany wygląd & 4,05 \\
\hline Poczucie humoru & 3,85 \\
\hline Pewność siebie & 3,80 \\
\hline Stosowny elegancki ubiór & 3,65 \\
\hline Własny styl bycia & 3,50 \\
\hline
\end{tabular}

Źródło: opracowano na podstawie wyników przeprowadzonych badań własnych. 
Tabela 10. Cechy zewnętrzne - wizerunek nauczyciela z autorytetem według opinii studentów Zachodniopomorskiego Uniwersytetu Technologicznego

\begin{tabular}{|l|c|}
\hline \multicolumn{1}{|c|}{ Cecha wykładowcy } & Średnia ocena cechy \\
\hline Kultura osobista & 4,75 \\
\hline Taktowność & 4,40 \\
\hline Pewność siebie & 4,40 \\
\hline Schludny zadbany wygląd & 4,20 \\
\hline Poczucie humoru & 3,90 \\
\hline Stosowny elegancki ubiór & 3,75 \\
\hline Własny styl bycia & 3,75 \\
\hline
\end{tabular}

Źródło: opracowano na podstawie wyników przeprowadzonych badań własnych.

Podczas przeprowadzonego badania zapytano respondentów również o odczucia wobec nauczyciela z autorytetem. Uzyskane odpowiedzi i procentową strukturę wskazań na wymienione odczucia prezentuje ryc. 2.

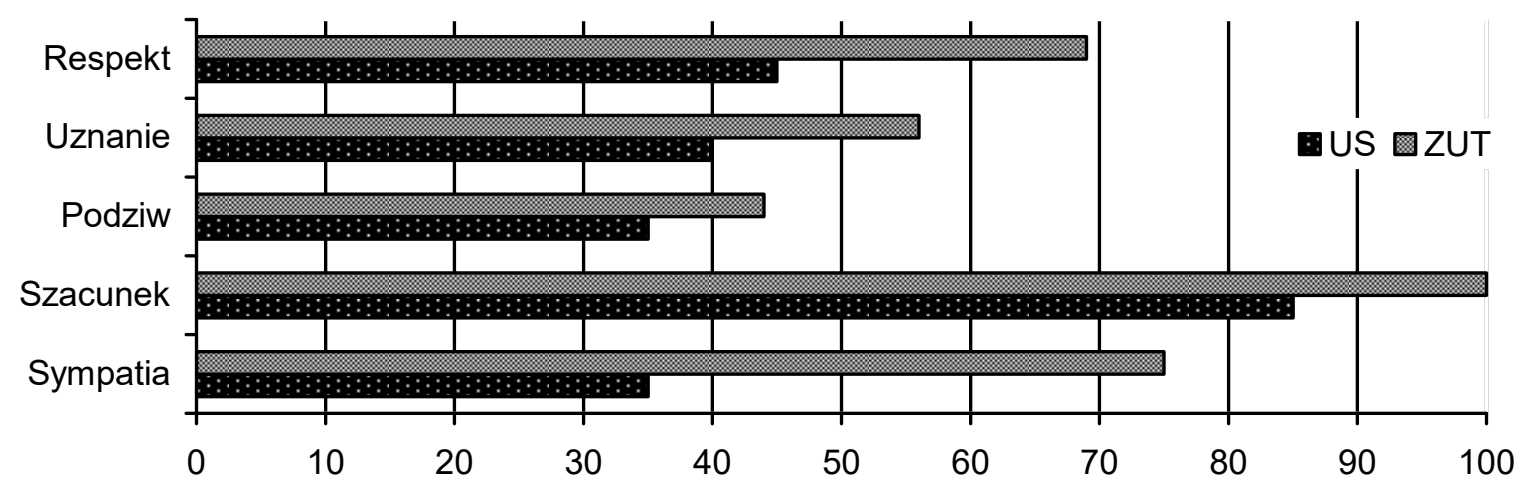

Ryc. 2. Wyniki badań ankietowych przeprowadzonych wśród studentów Uniwersytetu Szczecińskiego i Zachodniopomorskiego Uniwersytetu Technologicznego Źródło: opracowano na podstawie badań ankietowych.

Osoby, które uczestniczyły w badaniu ankietowym miały odpowiedzieć na pytanie, czy ich zdaniem każdy nauczyciel akademicki powinien być autorytetem dla studentów. Większość respondentów wskazała, że oczekuje tego, aby każdy nauczyciel akademicki stanowił dla nich autorytet (aż 75\% respondentów z Zachodniopomorskiego Uniwersytetu Technologicznego), natomiast respondenci z Uniwersytetu Szczecińskiego byli nieco mniej do tego przekonani (w $55 \%$ ).

Respondenci w trakcie prowadzonego badania zostali również zapytani o to, czy wśród wykładowców swoich uczelni są nauczyciele posiadający cechy nauczyciela z autorytetem. Przeprowadzone badania wykazały, że większość respondentów ma autorytety na swojej uczelni (56\% studentów z Zachodniopomorskiego Uniwersytetu Technologicznego i 62\% studentów z Uniwersytetu Szczecińskiego).

\section{PODSUMOWANIE}

Należy pamiętać, iż w nauce nie można wiedzieć absolutnie wszystkiego, dlatego autorytet zyska tylko ten nauczyciel, który wykaże się kompetencjami w dziedzinie, którą reprezentuje, przekazując wiedzę prawdziwą, bez uznawania jej za jedynie słuszną i obowiązującą w drodze wzajemnego dialogu (Bogusz 1996). 
$\mathrm{Na}$ podstawie przeprowadzonych badań można wskazać cechy pożądane przez studentów, jakimi powinien odznaczać się nauczyciel akademicki postrzegany jako autorytet. Przede wszystkim powinien to być człowiek uczciwy, który potrafi przyznawać się do własnych błędów i postępujący sprawiedliwie wobec swoich studentów. Powinien być obiektywny i otwarty zarówno na wiedzę, jak i na bezpośredni kontakt ze studentami. Człowiek ten powinien szanować poglądy innych osób i nie narzucać w sposób autorytatywny swoich poglądów.

Istotne jest, aby był on kompetentny merytorycznie i metodycznie oraz posiadał wiedzę zarówno praktyczną, jak i teoretyczną. Aspekt praktyczny miał zapewne bardzo istotne znaczenie dla respondentów dlatego, że byli oni studentami uczelni ekonomicznych, gdzie nabyta wiedza praktyczna jest niezbędna w późniejszej pracy zawodowej.

Wykładowca z autorytetem to także osoba, która powinna być komunikatywna, powinna przekazywać w sposób prosty i zrozumiały wiedzę swoim słuchaczom, przy uwzględnianiu ich potrzeb, zarażać ich pasją do dziedziny nauki, w której jest specjalistą. Osoba taka powinna zawsze być przygotowana do zajęć, przez co nie naraża się na krytykę ze strony studentów, że były one przeprowadzone w sposób niedbały, bez wzbudzenia zainteresowania wśród słuchaczy.

Wykładowca cieszący się autorytetem to także osoba o wysokiej kulturze osobistej i taktowna, niepozbawiona poczucia humoru, który pomaga często w nawiązywaniu pozytywnych relacji pomiędzy wykładowcą a studentami.

\section{PIŚMIENNICTWO}

Błędowska M. 1996. Autorytet - surowość w granicach taktu, www.eid.edu.pl/archiwum/1996,94/ /wrzesien, dostęp: 19.11.2016.

Bogusz J. 1996. Autorytet nauczyciela akademickiego a wyniki kształcenia i wychowania. Pedagog. Szk. Wyż. 4, 15-27.

CBOS. 2013. Aktualne problemy i wydarzenia, www.cbos.pl, dostęp: 10.11.2016.

Daszykowska J. 2012. Studenci o autorytecie nauczyciela akademickiego, www.pedkat.pl/.../247-daszykowska-jadwiga-studenci-o-autorytecie-nauczyciela-akad., dostęp: 10.11.2016.

Haber L.H. 1996. Przedsiębiorczość jako parametr pozycji rynkowej nauczyciela akademickiego. Pedagog. Szk. Wyż. 7, 65-77.

Nauczyciel i kształcenie nauczycieli. Zmiany i wyzwania. 2000. Red. W. Hörner. Warszawa, Wydaw. Żak, 40.

Jaskot K., Jazukiewicz I. 2006. Role zawodowe nauczyciela akademickiego, w: Wprowadzenie do pedagogiki szkoły wyższej. Red. J. Jaskot. Szczecin, Oficyna INplus, 308.

Łobocki M. 2007. Wychowanie moralne w zarysie. Kraków, IMPULS, 108-109.

Nowy leksykon PWN. 1998. Warszawa, PWN, 103.

Parsons T. 1971. The system of modern sociates. Nowy Jork, Englewood Cliffs, 84-85.

Polok G. 2010. Erozja autorytetu nauczyciela akademickiego - czy uwidaczniająca się tendencja może ulec zmianie? Ann. Etyka w Życiu Gospod. 13(2), 25-33.

Rumiński A. 1996. Nauczyciel akademicki wobec wartości życiowych. Pedagog. Szk. Wyż. 7, 81-92.

Śnieżyński M. 2000. O autorytecie nauczyciela akademickiego. Konspekt 3, www.wsp.krakow.pl/ konspekt3/sniezynski.html, dostęp: 18.11.2016.

Ustawa z dnia 27 lipca 2005 roku Prawo o szkolnictwie wyższym. DzU z 2005 r., nr 164, poz. 1365, z póź. zm. 
Wiczkowski W. 1996. Wartości moralne nauczyciela akademickiego. Pedagog. Szk. Wyż. 7, 158-162.

Wiśniewska M. 2011. Tożsamość nauczyciela akademickiego. Forum Dydakt. 7-8, 66-76.

Zbaraszewska A., Majchrzak I. 2016. Idealny wykładowca w opinii studentów. Folia Pomer. Univ. Technol. Stetin., Ser. Oeconomica 327(83)2, 309-318. 
